\title{
Local Revenue Mobilization in Romania
}

\author{
Octavian Moldovan*
}

\begin{abstract}
:
As public institutions are faced with more diverse and increased community needs, significant concern arises (both in academia and practice) for the dwindling resources available at the local level and the factors which can influence local revenue mobilization. Using data for 3,227 Romanian territorial-administrative (all Romanian territorial administrative units except Bucharest - the capital city), this research compares local revenue mobilization (calculated as: effectively collected revenues, as a share of what was predicted at the beginning of the budgetary year) for the 2008 - 2011 period, trying to determine if the type of a territorial administrative unit influences its public revenue mobilization.

The post hoc ANOVA showed that the type of a local institution (be it commune, city, municipality, county or sector) does not affect the level of revenue collection (proxied by collected/predicted revenues); where such relationships between these two variables were found, they were rather spurious and did not surfaced across the entire dataset.
\end{abstract}

Key words: Local public revenue collection/mobilization; Post Hoc ANOVA; Financial Decentralization; Collected vs. predicted public revenues.

J EL classification: H71, H72.

\section{Introduction}

As public administration is faced with increased and more diverse community needs, more and more concern is manifested (both in academia and in practice) for the dwindling resources available to local public institutions. Financial and administrative decentralization, once promoted as a mechanism that could ensure a better match between local needs and public resources, showed its limitations as smaller local governments had to provide increasingly more (state delegated) public services, often without having at their disposal adequate (financial, material and human) resources; consequentially, this led to further inequalities between local communities. Revenue mobilization (understood as the capacity of public sector organizations to collect financial resources from taxation and other sources - levies, licenses, royalties, etc.) has received considerable academic attention, especially in the context of developing countries and local governments (Akudugu and Oppong-Peprah, 2013; de Mello and Barenstein, 2001; Elezi, 2015; Opoku, Kyeremeh, and Odoom, 2014; African Development Bank Group, 2011; Danulețiu, 2010).

Octavian Moldovan; Babeş-Bolyai University, Public Administration and Management Department, Traian Moşoiu Street 71, 400132 Cluj-Napoca, Romania, <octavian.moldovan@ fspac.ro>. 
Aiming to provide a better understanding of local revenue mobilization in Romania $(\mathrm{N}=3,227)$, the main objective of this research is a dual one: (a) to present a descriptive analysis of local revenue mobilization in Romania for the 2008-2011 period and (b) to test if the type of a local administrative institution influences its revenue collection level (proxied by effectively collected revenues, as a share of what was predicted at the beginning of the budgetary year).

\section{Decentralization and the revenues of local public adminis tration}

The salience of revenue mobilization at the local level is often considered a result of financial/fiscal decentralization (Profiroiu and Profiroiu, 2006, p. 119), thus the two administrative processes need to be analyzed simultaneously. Ștefan and Dogaru (2011, p. 130) define decentralization as 'a mechanism by means of which the local administration authorities receive the authority and the resources allowing them to make decisions concerning the provision of public services', thus underlying the importance of financial decentralization as local governments should receive power/authority and responsibilities/duties as well as financial resources in order to act in the best interest of their communities. According to Rondinelli (1981, pp. 133-145) decentralization can be understood as the distribution of responsibility for planning, management and resource collection and allocation from the central government (and its agencies) to other public bodies; from this perspective, local revenue mobilization can be regarded as one of the more important aspects of decentralization.

Analyzing fiscal decentralization in transition countries, Dabla-Norris (2006, pp. 100-131) highlights that Romania, as an intermediate reformer: (a) has 'been less successful in establishing fiscal institutions, controlling fiscal imbalances, and redefining the role of the state' (p. 104); (b) still maintains a rather ambiguous distribution of spending responsibilities (p. 111); (c) has moved toward a more transparent system of transfers (between local and central governments), but the system is not yet perfect (p. 115); and (d) local governments achieve fairly high shares of 'own' revenue, most of which come from local taxes (p. 119).

Rodríguez-Pose and Krøijer (2009, p. 14) argue that, in healthy institutional and regulatory frameworks, independent subnational governments are more likely to lead to 'greater accountability and efficiency', but in the context of inadequate (lower) shares of subnational 'own source' revenues, local public authorities will remain dependent on shares of central taxes (or transfers), thus inhibiting the potential advantages of financial decentralization. Since Romanian local governments receive more than $40 \%$ of their revenues in the form of conditional grants (earmarked by the central government to support specific social sector functions), it can be easily argued that the financial autonomy of Romanian sub- 
national tiers is rather limited (Network of Associations of Local Authorities of South-East Europe - NALAS, 2012, p. 25). A similar view is shared by Cristinel (2012), providing evidence that even if the principles of autonomy and decentralization of public services are frequently invoked in the public sphere, local territorial administrative units are 'dependent on transfers of funds from the state' (p. 920), thus limiting their real autonomy from a financial point of view.

Looking further into decentralization, Gershberg (2008) argues that decentralization policies often rely on (or at least require) the existence of a formula to allocate funding for subnational governments in order to ensure that they have sufficient financial resources to fulfil their responsibilities (p. 1). However, Romania 'has failed in the eyes of many analysts to develop any serious formula funding mechanisms' until 2008, mainly due to 'politics and power' (Gershberg, 2008, p. 1); in other words, decision makers from the central level avoided the development and transparent implementation of a formula for transferring funds towards local authorities in order to maintain a degree of freedom that would allow them to reward 'loyal' (same political color) communities/local governments from the sub-national level, thus leading to uneven local development and service provision. The same argument was made earlier by Ioniţă (2005) for general purpose, infrastructure and pre-university education funds (making this a potentially endemic problem of the Romanian public finance system) while Marian and King (2016) observed that government spending seems to be (at least) decoupled from the policy preferences of citizens.

Analyzing the administrative levels by which decentralization (fiscal and other) is exercised, NALAS (2012, p. 13) identifies 'four levels of sub-sovereign government' in Romania, which are grouped in two tiers. Three of these levels (communes, cities and municipalities) are assessed to be 'first-tier levels of local government' and have similar rights and responsibilities, while the second tier (the county level) is assessed to be at 'the provincial level'. However, the same report (NALAS, 2012, p. 13) argues that communes, municipalities and cities (or the first tier) have a more important function as sub-national governments 'in both fiscal terms and public service terms', as well as a more direct contact to the citizenry. According to the Institute for Public Policies (Institutul pentru Politici Publice IPP) a cleavage seems to develop between local communities that manage to obtain sufficient revenues from own sources and those that do not collect enough revenues (even for paying their utilities and staff) (IPP, 2001, p. 9).

Economic, social and demographic advantages offer enough resources for some communities to undergo a continuous and equilibrated development process, but others are both less fortunate and also blamed for their inability to collect local resources (even when the tax base is present); thus rich communities lose sight of the primordial European concept that development is built on economic and social 
cohesion (IPP, 2001, p. 9) and not on assigning blame. Political pressure and discretionary power (at the central level) should also be taken into account as they can be used to supplement (via transfers) certain local budgets for political and electoral purposes, thus skewing the distribution of local revenues between different territorial-administrative units (Iorga, Moraru and Giosan, 2010, p. 6). Other factors which can influence local revenue mobilization refer to: the competence of revenue specialized clerks/public servants (Ndunda, Ngahu and Wanyoike, 2015), corruption (Brașoveanu and Obreja Brașoveanu, 2013, pp. 167184), economic and financial crises (IMF, 2015), weak institutional capacity, informal and agricultural economies, tax evasion/avoidance, tax exemptions, inequitable rent-sharing (Mascagni, Moore and McCluskey, 2014, p. 4) loopholes in income taxation frameworks, lack of transparency in revenue collection and remittance processes (Gideon and Alouis, 2013) and deficient organizational capacity to accurately estimate local revenues and their collection (Moldovan and Macarie, 2015).

\section{Data and Methodology}

The data used for this study was obtained from The Direction for Fiscal Policies and Local Budgets (DFPLB, 2013) and it is publicly available for researchers interested in the level of revenue collection in Romania (this can be considered one of the successful instances of transparency applied in the Romanian public sector). The final SPSS database created for this research included the names and types of territorial-administrative units (t.a.u. from here on) and the level of revenue collection (in percentages: what was actually collected at the end of the budgetary year as a share of what was predicted at the beginning of the budgetary year) for 2008, 2009, 2010 and 2011, for 3,227 Romanian local territorialadministrative units (all Romanian t.a.u.s without Bucharest, the capital city).

The level of revenue collection will be used as a dependent variable, while the type of territorial-administrative units will be used as the independent (explanatory) variable. Revenue collection levels for the 2008-2011 period, the dependent variable of this research, are ratio data, calculated by the following formula: revenues effectively collected (at the end of the budgetary year) divided by revenues predicted or proposed (at the beginning of the budgetary year). This indicator was used as a proxy for revenue mobilization in Romania because it allows comparisons between different t.a.u. types, which would be impossible/irrelevant to do with other indicators (such as the total collected revenues in monetary units) given the factual differences in tax bases between these territorial administrative units. 
Romanian territorial-administrative units, used as independent variables, are nominal data and consist of five categories: county (județ), municipality (municipiu), city (oraș), commune (comună), and sector (sector). Although the aforementioned five types of t.a.u.'s share some commonalities (such as the existence of: elected officials and civil servants, juridical or juristic personality, endowment with public authority, public property, financial and administrative autonomy - own budgets, with revenues and expenses), there are also consistent differences between them, especially regarding the available tax base and their administrative capacity, differences which warranted this comparison.

Counties represent the immediate administrative level below the national one and they are tasked with the coordination of municipalities, cities and communes from their jurisdiction (Romanian Constitution, 2003); they are Romania's NUTS-3 territorial units.

Sectors are administrative units of the Municipality of Bucharest (which has the same administrative level as that of a county - NUTS-3), with responsibilities over local affairs, such as secondary streets, hospitals, parks, schools, cleaning services and so on; the average population of each sector (between 225,000 and 385,000 inhabitants) and their potential tax bases are comparable with that of medium and smaller counties.

Municipalities, cities and communes represent the first (lowest) sub-national level/tier of government and are more close to local communities/settlements (i.e. the closest level to the citizenry), are autonomous (from a financial and administrative perspective) and there are no other administrative subdivisions bellow them. The main differences between municipalities (urban settlements), cities (urban settlements) and communes (rural settlements) refer to: the number of inhabitants, the percentage of the population engaged in non-agricultural activities, water, electrical, heating and sewage facilities, healthcare, tourism and educational facilities/services, transportation, recreational and public parks infrastructure and so on (Romanian Parliament, 2007). Furthermore, a local community can transform its t.a.u. type between these previous three categories following the fulfilment of certain criteria, two or more communities can merge or a new commune can be founded by splitting itself from another existing municipality/city or commune (if certain requirements are fulfilled). 


\section{Local revenue mobilization in Romania}

\subsection{Descriptive/exploratory analysis}

The level of revenue collection/mobilization was analyzed for all Romanian territorial-administrative units (except Bucharest) according to the type of community. A general analysis for the 2008-2011 period is presented in Tab. 1 . The lowest levels of revenue collection for 2008 and $2009(0.00 \%)$ can be explained by the fact that a new territorial administrative unit was established in 2010, namely the commune of Racşa (in the county of Satu Mare), by reorganizing (splitting from) the commune of Oraşu Nou (Romanian Parliament, 2010). Since data for this case was not available in 2008 and 2009 as the commune did not exist, the minimum was 0 .

The average level of revenue mobilization for 2008 stands at $79.40 \%$ from what was predicted, the minimum (excepting Racşa) being $11.02 \%$ and the maximum $167.15 \%$, with a range of 156.13 . For 2009 , the average level of revenue collection is $78.69 \%$, the minimum (excepting Racşa) being $17 \%$ and the maximum $127.34 \%$, with a range of 110.34 . In 2010 , the average level of revenue collection was higher than in previous years $(82.84 \%)$; higher values also occurred for the minimum (25.93\%), maximum (172.70\%) and the range (146.77). In 2011, the average level of mobilization was even higher $(84.60 \%)$, but both the minimum $(24.00 \%)$ and maximum (134.80\%) were lower than in the previous year.

Tab. 1: Collected/predicted revenues - general descriptive statistics (2008-2011)

\begin{tabular}{|c|c|c|c|c|c|c|c|c|}
\hline Year of analysis & $\mathbf{N}$ & Range & Min. & Max. & $\begin{array}{r}\text { Mean } \\
\text { (Std. Er.) }\end{array}$ & Std.Dev. & $\begin{array}{r}\text { Skewness } \\
\text { (Std. Er.) }\end{array}$ & $\begin{array}{l}\text { Kurtosis } \\
\text { (Std. Er.) }\end{array}$ \\
\hline $\begin{array}{l}\text { Collection levels } \\
2008\end{array}$ & 3,227 & 167.15 & 0.00 & 167,15 & $\begin{array}{l}79.376 \\
(0.271)\end{array}$ & 15.415 & $\begin{array}{r}-0.778 \\
(0.043)\end{array}$ & $\begin{array}{r}1.553 \\
(0.086)\end{array}$ \\
\hline $\begin{array}{l}\text { Collection levels } \\
2009\end{array}$ & 3,227 & 127.34 & 0.00 & 127,34 & $\begin{array}{l}78.671 \\
(0.259)\end{array}$ & 14.694 & $\begin{array}{r}-0.822 \\
(0.043)\end{array}$ & $\begin{array}{r}1.032 \\
(0.086)\end{array}$ \\
\hline $\begin{array}{l}\text { Collection levels } \\
2010\end{array}$ & 3,227 & 146.77 & 25.93 & 172,70 & $\begin{array}{l}82.845 \\
(0.221)\end{array}$ & 12.529 & $\begin{array}{r}-0.636 \\
(0.043)\end{array}$ & $\begin{array}{r}1.405 \\
(0.860)\end{array}$ \\
\hline $\begin{array}{l}\text { Collection levels } \\
2011\end{array}$ & 3,227 & 110.80 & 24.00 & 134,80 & $\begin{array}{l}84.637 \\
(0.218)\end{array}$ & 12.389 & $\begin{array}{r}-0.910 \\
(0.043)\end{array}$ & $\begin{array}{r}1.052 \\
(0.086)\end{array}$ \\
\hline
\end{tabular}

Source: authorial computation based on DFPLB (2013) data.

In order to obtain a better understanding of how the data is spread (how did territorial-administrative units manage to collect their revenues), Skewness and Kurtosis were also analyzed. Skewness is a measure of symmetry (the distribution is symmetric if it looks the same to the left and right of the center point); the 
Skewness for a normal distribution is zero, and any symmetric data should have a Skewness near zero. In the case of revenue collection levels (Tab. 1), the distribution presents a small skew to the left, which means that the tail on the left side of the probability density function is longer than the right side and the bulk of the values (possibly including the median) lie to the right of the mean. In simpler terms, multiple territorial-administrative units managed to collect their revenues above the average. Kurtosis is a measure of whether the data are peaked or flat relative to a normal distribution (data sets with high kurtosis tend to have a distinct peak near the mean, decline rather rapidly, and have heavy tails, while data sets with low kurtosis tend to have a flat top near the mean rather than a sharp peak). A higher kurtosis means that more of the variance is the result of infrequent extreme deviations, as opposed to frequent modestly sized deviations. The analysis (presented earlier in Tab. 1) shows relatively low values for Skewness, suggesting that variations between the levels of revenue collection between different territorial-administrative units are rather modest in size (although the tail extends to the left). The Kurtosis, although presents differences between the four years, is smaller than 2, thus in the limits of normal distribution.

Although using the aforementioned indicators we can approximate a rather normal distribution of revenue collection levels across our data, more insights can be gained if we analyze the 2008-2011 trends for each type of community (Tab. 2).

Tab. 2: Collected/predicted re venues by t.a.u. type, selected indicators (2008-2011)

\begin{tabular}{|c|c|c|c|c|c|c|}
\hline $\begin{array}{l}\text { Type of } \\
\text { community }\end{array}$ & $\begin{array}{l}\text { Selected } \\
\text { statistics }\end{array}$ & 2008 & 2009 & 2010 & 2011 & $\mathbf{N}$ \\
\hline \multirow[t]{6}{*}{ Municipality } & Mean & $81.87(\%)$ & $82.30(\%)$ & $83.98(\%)$ & $84.09(\%)$ & \multirow{6}{*}{102} \\
\hline & Minimum & $34.00(\%)$ & $56.80(\%)$ & $63.90(\%)$ & $45.28(\%)$ & \\
\hline & Maximum & $102.57(\%)$ & $102.65(\%)$ & $100.26(\%)$ & $100(\%)$ & \\
\hline & Range & 68.47 & 45.85 & 36.36 & $54.72(\%)$ & \\
\hline & Skewness & -1.245 & -0.278 & -0.106 & 0.238 & \\
\hline & Kurtosis & 2.187 & 0.256 & -0.582 & 0.472 & \\
\hline \multirow[t]{6}{*}{ City } & Mean & $79.69(\%)$ & $79.78(\%)$ & $81.25(\%)$ & $82.33(\%)$ & \multirow{6}{*}{217} \\
\hline & Minimum & $23.00(\%)$ & $41.00(\%)$ & $33.30(\%)$ & $38.24(\%)$ & \\
\hline & Maximum & $103.28(\%)$ & $107.94(\%)$ & $104.16(\%)$ & $109.98(\%)$ & \\
\hline & Range & 80.28 & 66.94 & 70.86 & 71.74 & \\
\hline & Skewness & -1.061 & -0.720 & -0.662 & -0.663 & \\
\hline & Kurtosis & 1.070 & 0.280 & 0.892 & 0.105 & \\
\hline
\end{tabular}


Moldovan, O.: Local Revenue Mobilization in Romania.

\begin{tabular}{llrrrrr}
\hline $\begin{array}{l}\text { Type of } \\
\text { community }\end{array}$ & $\begin{array}{l}\text { Selected } \\
\text { statistics }\end{array}$ & \multicolumn{1}{l}{ 2008 } & \multicolumn{1}{l}{ 2009 } & \multicolumn{1}{l}{ 2010 } & \multicolumn{1}{l}{$\mathbf{2 0 1 1}$} & N \\
\hline Commune & Mean & $79.25(\%)$ & $78.43(\%)$ & $82.91(\%)$ & $84.82(\%)$ & \\
& Minimum & $0(\%)$ & $0(\%)$ & $25.93(\%)$ & $24.00(\%)$ & \\
& Maximum & $167.15(\%)$ & $127.34(\%)$ & $172.70(\%)$ & $134.80(\%)$ & \multirow{2}{*}{ (\%,861 } \\
& Range & 167.15 & 127.34 & 146.77 & $110.80(\%)$ & \\
& Skewness & -0.739 & -0.800 & -0.636 & -0.921 & \\
& Kurtosis & 1.512 & 0.927 & 1.348 & 1.079 & \\
\hline Sector & Mean & $85.39(\%)$ & $87.98(\%)$ & $91.92(\%)$ & $92.53(\%)$ & \\
& Minimum & $73.17(\%)$ & $81.97(\%)$ & $83.62(\%)$ & $76.29(\%)$ & \\
& Maximum & $95.33(\%)$ & $100.20(\%)$ & $99.99(\%)$ & $99.98(\%)$ & \\
& Range & 22.16 & 18.03 & 16.37 & 23.69 & \\
& Skewness & -0.462 & 1.079 & -0.077 & -1.750 & \\
& Kurtosis & 0.641 & -0.499 & 1.686 & 3.352 & \\
\hline County & Mean & $79.15(\%)$ & $78.37(\%)$ & $82.29(\%)$ & $84.10(\%)$ & \\
& Minimum & $53.90(\%)$ & $56.62(\%)$ & $72.12(\%)$ & $74.76(\%)$ & \\
& Maximum & $93.30(\%)$ & $91.67(\%)$ & $96.53(\%)$ & $96.64(\%)$ & \\
& Range & 39.42 & 35.05 & 24.40 & 21.88 & 4 \\
& Skewness & -1.398 & -0.958 & 0.104 & 0.275 & \\
& Kurtosis & 3.210 & 1.578 & 0.331 & -0.165 & \\
\hline
\end{tabular}

Source: authorial computation based on DFPLB (2013) data.

In 2008 (Tab. 2), sectors managed to reach the highest level of revenue collection (Mean $=85.39 \%)$, followed by municipalities (81.87\%), cities $(79.69 \%)$, communes $(79.28 \%)$ and counties $(79.15 \%)$, albeit the differences between them are small. The most extreme values can be found in communes (with the exception of Racşa), as the commune that performed the weakest only managed to collect $11.02 \%$ of predicted revenues and the commune that performed the best collected no less than $167.15 \%$ of the predicted revenues. The same pattern can be observed in 2009 (Tab. 2), as (on average) sectors collected $87.98 \%$ of predicted revenues, municipalities $82.30 \%$, cities $79.78 \%$, communes $78.43 \%$ and counties $(78.37 \%$ ). Extreme values can be found in communes, with a minimum of $17.00 \%$ (even if we exclude Racşa from the analysis) and a maximum of $127.47 \%$ of predicted revenues.

For 2010 (Tab. 2) the data presents a slighter changed picture, as the averages for communes and counties are higher than the average for cities; thus sectors managed to collect the highest percentage of their predicted revenues $(91.92 \%)$, followed by municipalities $(83.98 \%)$, communes $(82.91 \%)$, counties $(82.29 \%)$ and cities $(81.25 \%)$. However, the lowest $(25.93 \%)$ and highest $(172.70 \%)$ levels of revenue collection are found, yet again, in communes. In 2011, communes also managed to overtake municipalities, thus sectors (92.53\%) lead the ranking, 
followed by communes (84.82\%), counties $(84.10 \%)$, municipalities $(84.09 \%)$ and cities $(82.33 \%)$. Similar to previous years, the values for communes vary the most leading to the biggest range, with a minimum of $25.93 \%$ and a maximum of $172.70 \%$.

A visual representation of the 2008-2011 data (see Fig. 1 to Fig. 4 in Appendix) provides further initial evidence for the existence of differences in local revenue mobilization and that these differences can be connected with the administrative type/classification of a local institution.

\subsection{Confirmatory research}

In order to confirm the aforementioned hypothesis/observation (that the differences that occur between different types of communities with regard to their levels of revenue collection/mobilization are statistically significant) an analysis of variance is required. The one-way analysis of variance (ANOVA) is used to determine whether there are any statistically significant differences between the means of three or more independent (unrelated) groups, by comparing the means between the groups and determining whether any of those means are significantly different from each other. Specifically, it tests the null hypothesis:

$$
\mathrm{H} 0: \mu 1=\mu 2=\mu 3=\ldots . .=\mu \mathrm{k},
$$

Where $\mu_{i}=$ group mean and $k=$ number of groups. If, however, the one-way ANOVA returns a significant result then we accept the alternative hypothesis $\left(\mathrm{H}_{\mathrm{A}}\right)$, which is that there are at least 2 group means that are significantly different from each other. The basic assumptions that have to be met in order to realize a one-way ANOVA are presented below, as well as the degree to which they are respected by the data used in this research.

The first assumption is that the independent variable consists of two or more categorical independent groups. Categorical variables represent types of data which may be divided into groups that are independent from each other - given the nature of our data, this criterion is meet. The second assumption is that the dependent variable is either interval or ratio (continuous); this assumption is also meet since the dependent variable refers to the levels of revenue collection (collected/predicted local revenues) for 2008, 2009, 2010 and 2011 (ratio measurement). The third assumption is that the dependent variable is approximately normally distributed for each category of the independent variable this condition was observed in Tab. 1 and 2. The fourth assumption - equality of variances between the independent groups (homogeneity of variances will be tested in SPSS using Levene's Test and the Robust Tests of Equality of Means). The last (fifth) assumption, independence of cases is also meet by our data. 
One of the most important assumptions of the one-way ANOVA is that the variances of the compared groups are similar. The Test of Homogeneity of Variances (Tab. 3) shows the result of Levene's Test of Homogeneity of Variance, which tests for similar variances. If the significance value is greater than .05 (found in the Sig. column) then there is homogeneity of variances. Unfortunately, the data fails to meet the assumption of homogeneity of variance, as the Sig. values are lower than .05, thus we will refer to the Robust Tests of Equality of Means (Tab. 3), instead of the usual ANOVA table.

Tab. 3: Homogeneity of variances tests (Collected/predicted re venues by t.a.u. type, 2008-2011)

\begin{tabular}{lrrrr}
\hline \multirow{2}{*}{ Year of analysis } & Levene's test & \multicolumn{3}{c}{ Robust Tests of Equality of Means } \\
& Levene Statistic & Sig. & Welch Statistic & \multicolumn{1}{c}{ Sig. } \\
\hline 2008 & 8.849 & 0.00 & 1.962 & 0.122 \\
2009 & 14.215 & 0.00 & 6.891 & $0.000^{*}$ \\
2010 & 13.066 & 0.00 & 5.760 & $0.001^{*}$ \\
2011 & 8.941 & 0.00 & 3.106 & $0.028^{*}$ \\
\hline
\end{tabular}

Source: authorial computation based on DFPLB (2013) data.

Note: * the mean difference is significant at the 0.05 level.

The significance level in the case of the Welch Statistic is below .00 for 2009, 2010 and 2011 therefore, for these years, there is a statistically significant difference in the means of the revenue collection levels between the four types of communities (local public organizations). The significance for 2008 is .122, which is above the .05 threshold, thus in this case there is no statistically significant difference between the groups (different types of institutions). As a result, this year will be excluded from the following (post hoc) analyses, as there are no significant differences between types of communities in 2008. However, for 2009, 2010 and 2011 although there is a statistically significant difference between the groups, we do not know (at this point) which of the specific groups differ. To reach a better understanding regarding the types of local institutions between which there is a significant difference we will continue by conducting post hoc tests (Tab. 4) (the post hoc test recommended in our case is Games-Howell because it does not rely on homogeneity of variance - assumption that is not meet by our data). 
Tab. 4: Post Hoc ANOVA Analysis, multiple comparisons, Games-Howell (Collected/predicted re venues by t.a.u. type, 2009-2011)

\begin{tabular}{|c|c|c|c|c|c|c|c|}
\hline (I) TAU Type & $\begin{array}{l}\text { (J) TAU } \\
\text { Type }\end{array}$ & $\begin{array}{l}\text { Mean } \\
\text { Difference } \\
\text { (I-J) } 2009\end{array}$ & Sig. & $\begin{array}{l}\text { Mean } \\
\text { Difference } \\
\text { (I-J) } 2010\end{array}$ & Sig. & $\begin{array}{l}\text { Mean } \\
\text { Difference } \\
\text { (I-J) } 2011\end{array}$ & Sig. \\
\hline \multirow{4}{*}{ County } & Municipality & -3.996 & 0.052 & -1.764 & 0.563 & 0.0314 & 1.000 \\
\hline & City & -1.403 & 0.867 & 1.037 & 0.886 & 1.765 & 0.567 \\
\hline & Commune & -0.059 & 1.000 & -0.615 & 0.950 & -0.723 & 0.897 \\
\hline & Sector & -9.607 & 0.115 & $-9.633^{*}$ & 0.028 & -8.429 & 0.255 \\
\hline \multirow{4}{*}{ Municipality } & County & 3.996 & 0.052 & 1.764 & 0.563 & -0.0314 & 1.000 \\
\hline & City & 2.593 & 0.209 & 2.801 & 0.104 & 1.734 & 0.726 \\
\hline & Commune & $3.937^{*}$ & 0.000 & 1.149 & 0.685 & -0.754 & 0.959 \\
\hline & Sector & -5.611 & 0.462 & -7.868 & 0.068 & -8.461 & 0.258 \\
\hline \multirow{4}{*}{ City } & County & 1.403 & 0.867 & -1.037 & 0.886 & -1.765 & 0.567 \\
\hline & Municipality & -2.593 & 0.209 & -2.801 & 0.104 & -1.734 & 0.726 \\
\hline & Commune & 1.344 & 0.572 & -1.652 & 0.242 & -2.489 & 0.057 \\
\hline & Sector & -8.204 & 0.189 & $-10.667^{*}$ & 0.018 & -10.195 & 0.149 \\
\hline \multirow{4}{*}{ Commune } & County & 0.059 & 1.000 & 0.615 & 0.950 & 0.723 & 0.897 \\
\hline & Municipality & $-3.937^{*}$ & 0.000 & -1.149 & 0.685 & 0.754 & 0.959 \\
\hline & City & -1.344 & 0.572 & 1.652 & 0.242 & 2.489 & 0.057 \\
\hline & Sector & -9.548 & 0.117 & $-9.018^{*}$ & 0.043 & -7.707 & 0.310 \\
\hline \multirow{4}{*}{ Sector } & County & 9.607 & 0.115 & $9.633^{*}$ & 0.028 & 8.429 & 0.255 \\
\hline & Municipality & 5.611 & 0.462 & 7.868 & 0.068 & 8.461 & 0.258 \\
\hline & City & 8.204 & 0.189 & $10.667^{*}$ & 0.018 & 10.195 & 0.149 \\
\hline & Commune & 9.548 & 0.117 & $9.018^{*}$ & 0.043 & 7.707 & 0.310 \\
\hline
\end{tabular}

Source: authorial computation bas ed on DFPLB (2013) data.

Note: * the mean difference is significant at the 0.05 level.

In 2009, the only difference between the means that is statistically significant occurs between municipalities and communes. On average, municipalities managed to collect 3.93 percentage points more than communes $(\mathrm{p}<.05)$; all other differences observed in the previous analyses between different territorial administrative units are not statistically significant (Tab. 4).

In 2010, sectors seemed to have outperformed other types of communities, except municipalities (Tab. 4). The difference between sectors and counties is 9.63 $(\mathrm{p}<.05)$, which means that, on average sectors collected 9.63 percentage points more revenues (from what was predicted) than municipalities. The difference between sectors and communes is smaller $(9.01, \mathrm{p}<.05)$, meaning that sectors collected 9.01 percentage points more than communes. The biggest difference between means is observed in the case of cities $(10.66, \mathrm{p}<.05)$ as sectors collected 
10.66 percentage points more revenues than cities (compared to the initial forecasts). In 2011, none of the differences are statistically significant.

Referring to the original question (Does the type of local institution matter in the case of revenue mobilization/collection?) this analysis offers useful insights. First of all, for 2008 and 2011 none of the differences between the means of different types of local territorial administrative units were statistically significant. The data for 2009 showed that the only statistically significant difference was between communes and municipalities. However, in 2010 this difference lost its statistical significance, as only sectors managed to collect significantly more revenues than other types of communities, except for municipalities (where the difference also existed but was not statistically significant).

The aforementioned analyses (especially Tab. 4) provides enough evidence to refute all null hypotheses related to the existence of possible relationships between revenue collection levels (collected/predicted revenues) and different types of local institutions. As such, we must accept the hypotheses that the revenue collection levels of different types of communities are not statistically different for the overall period. Thus, the analysis corroborated the following hypotheses:

- H1: Between 2008 and 2011, the revenue collection levels of counties are not statistically different $(\mathrm{p}<.05)$ compared to the revenue collection levels of other types of territorial-administrative units (when compared to the initial forecasts).

- H2: Between 2008 and 2011, the revenue collection levels of municipalities are not statistically different $(\mathrm{p}<.05)$ compared to the revenue collection levels of other types of territorial-administrative units (when compared to the initial forecasts).

- H3: Between 2008 and 2011, the revenue collection levels of cities are not statistically different $(\mathrm{p}<.05)$ compared to the revenue collection levels of other types of territorial-administrative units (when compared to the initial forecasts).

- H4: Between 2008 and 2011, the revenue collection levels of communes are not statistically different $(\mathrm{p}<.05)$ compared to the revenue collection levels of other types of territorial-administrative units (when compared to the initial forecasts).

- H5: Between 2008 and 2011, the revenue collection levels of sectors are not statistically different $(\mathrm{p}<.05)$ compared to the revenue collection levels of other types of territorial-administrative units.

The aforementioned analyses provide support to the hypothesis that the type of a local public institution has no (or just spurious) effect on the level of revenue collection or mobilization (measured by collected/predicted revenues) attained. 


\section{Conclusion}

The analyses presented in this paper offer useful insights, for both policy makers and academia, regarding the relationship between levels of revenue collection (calculated as effectively collected revenues as a share of what was predicted at the beginning of the budgetary year) and types of local administrative institutions. Across the analyzed period, the type of sub-national governments (be it communes, cities, municipalities, counties or sectors) does not affect the levels of revenue mobilization/collection; where such relationships between these two variables were found, they were rather spurious and did not surfaced across the entire analyzed period.

The research findings mentioned thus far become even more important if we integrate them in the current discussions regarding the factors that influence revenue mobilization. There are significant differences between the local institutional types analyzed, in terms of population size and economic development (lower for communes, higher for cities), competence of revenue specialized clerks/public servants (lower for communes, higher for cities), overall institutional capacity (lower for communes), reliance on agricultural economy (higher for communes), but these differences do not seem to influence revenue mobilization (proxied by collected/predicted revenues), thus refuting some of the previous findings existent in the literature. Furthermore, we can assume that other factors, most likely of cultural origins have a significant influence on revenue collection, but the literature is rather scarce in this regard; however, the impact of cultural factors on revenue mobilization can constitute an interesting approach and area for future research.

\section{References}

African Development Bank Group, 2011. Domestic Resource Mobilisation for Poverty Reduction in East Africa: Lessons for Tax Policy and Administration. African Development Bank, Tunis.

Akudugu, J. A., Oppong-Peprah, E., 2013. Local Government Revenue Mobilisation and Management: The Case of Asante Akim South District. Journal of Public Administration and Governance 2, 98-120. DOI: 10.5296/jpag. v3i2.3977.

Brașoveanu, I. V., Obreja Brașoveanu, L., 2013. Public Sector Influences in the Development of Underground Economy and Corruption in Romania, in EU Context. Economic Computation and Economic Cybernetics Studies and Research 1, 167-184.

Cristinel, I., 2012. Financial Side Analysis of Local Autonomy in Romania. Anale. Seria Știinte Economice. Timişoara 18, 915-921. 
Dabla-Norris, E., 2006. The Challenge of Fiscal Decentralisation in Transition Countries. Comparative Economic Studies 48, 100-131. DOI: 10.1057/palgrave. ces. 8100063.

Danulețiu, D. C., 2010. Fiscal Decentralization and Issues of Municipal Bonds. The Case of Romania. Polish Journal of Management Studies 1, 70-78.

de Mello, L., Barenstein, M., 2001. Fiscal Decentralization and Governance: A Cross-Country Analysis. IMF Working Paper WP/01/71, Washington, D.C., IMF. DOI: 10.5089/9781451849240.001.

Elezi, S., 2015. Local Governance in an International Comparative Perspective. Comparing Local Government Finances in Macedonia with Slovenia. European Scientific Journal 13, 519-538.

Gershberg, A. I., 2008. The Realpolitiks of Decentralization and Formula Funding in Romania: A Confounding Case Study. Paris, UNESCO.

Gideon, Z., Alouis, M., 2013. Systems, Processes and Challenges of Public Revenue Collection in Zimbabwe. American International Journal of Contemporary Research 2, 49-60.

IMF, 2015. Current Challenges in Revenue Mobilization: Improving Tax Compliance. Washington, D.C., IMF.

Institutul pentru Politici Publice, 2001. Bugetele Locale între Teorie şi Practică. IPP, Bucureşti.

Ioniţă, S., 2005. Money for Our People? Decentralisation and Corruption in Romania: The Cases of the Equalisation, Infrastructure and Pre-university Education Funds. Public Administration and Development 3, 251-267. DOI: 10.1002/pad.365.

Iorga, E., Moraru, A., Giosan, V., 2010. Argument. In Iorga, E., Moraru, A., Giosan, V. Bugetele Autorităţilor Locale din România la Cote de Avarie: Politici de Finanţare Incoerente şi Excesiva Politizare a Procesului de Alocare a Resurselor. Bucureşti, IPP, 5-7.

Marian, C. G., King, R. F., 2016. Political Opinion and the Trends in Romanian Government Expenditures. Transylvanian Review of Administrative Sciences 48E, 54-65.

Mascagni, J., Moore. M., McCluskey, R., 2014. Tax Revenue Mobilisation in Developing Countries: Issues and Challenges. Brussels, EP Publication Office. DOI: $10.2861 / 58312$.

Moldovan, O., Macarie, F. C., 2015. Reducing Uncertainty in Romanian Public Finances: Forecasting Models for Revenue Collection. Procedia Economics and Finance 32, 1550-1567. DOI: 10.1016/s2212-5671(15)01545-2. 
Ndunda, J. M., Ngahu, S. T., Wanyoike, D., 2015. Analysis of Factors Influencing Optimal Revenue Collection by County Governments in Kenya. International Journal of Economics, Commerce and Management 5, 1114-1129.

Network of Associations of Local Authorities of South-East Europe-NALAS, 2012. Fiscal Decentralization Indicators for South-East Europe Report. Skopje, NALAS.

Opoku, E., Kyeremeh, C., Odoom, D., 2014. Local Revenue Mobilization Mechanisms: Evidence from the Abura-Asebu-Kwamankese District in Ghana. Developing Country Studies 26, 125-137.

Profiroiu, M., Profirou, A., 2006. Decentralization Process in Romania. Transylvanian Review of Administrative Sciences 16E, 115-123.

Rodríguez-Pose, A., Krøijer, A., 2009. Fiscal Decentralization and Economic Growth in Central and Eastern Europe. LSE 'Europe in Question' Discussion Paper Series no. 12/2009, London School of Economics. DOI: 10.2139/ssrn. 1550917.

Romanian Parliament, 2007. Legea nr. 100 din 2007 pentru modificarea şi completarea Legii nr. 351/2001 privind aprobarea Planului de amenajare a teritoriului naţional - Secţiunea a IV-a - Reţeaua de localităţi. Official Gazette of Romania 284.

Romanian Parliament, 2010. Legea nr. 86 din 2010 pentru înfiinţarea comunei Racşa, judeţul Satu Mare, prin reorganizarea comunei Oraşu Nou. Official Gazette of Romania 342.

Rondinelli, D. A, 1981. Government Decentralization in Comparative Perspective: Theory and Practice in Developing Countries. International Review of Administrative Sciences 2, 133-145. DOI: 10.1177/002085238004700205.

Ștefan, M. C., Dogaru, M., 2011. Implications of Financial Decentralization on the Local Budgets Balancing Policy. Knowledge Horizons - Economics 3-4, 130-135.

The Constitution of Romania, 2003. Legea nr. 429 din 2003 de revizuire a Constituţiei României. Official Gazette of Romania 758.

The Direction for Fiscal Policies and Local Budgets (DFPLB), 2013. Gradul de colectare în anii 2008, 2009, 2010 şi 2011 - pe UAT-uri, tipuri de UAT-uri şi pe judeţe. Available from: <http://www.dpfbl.mai.gov.ro/analize_bugete.html.> [8 June 2015]. 


\section{Appendix: Graphical representation of local revenue mobilization} (2008-2011)

\section{Fig. 1: Collected/predicted revenues by t.a.u. type in 2008}

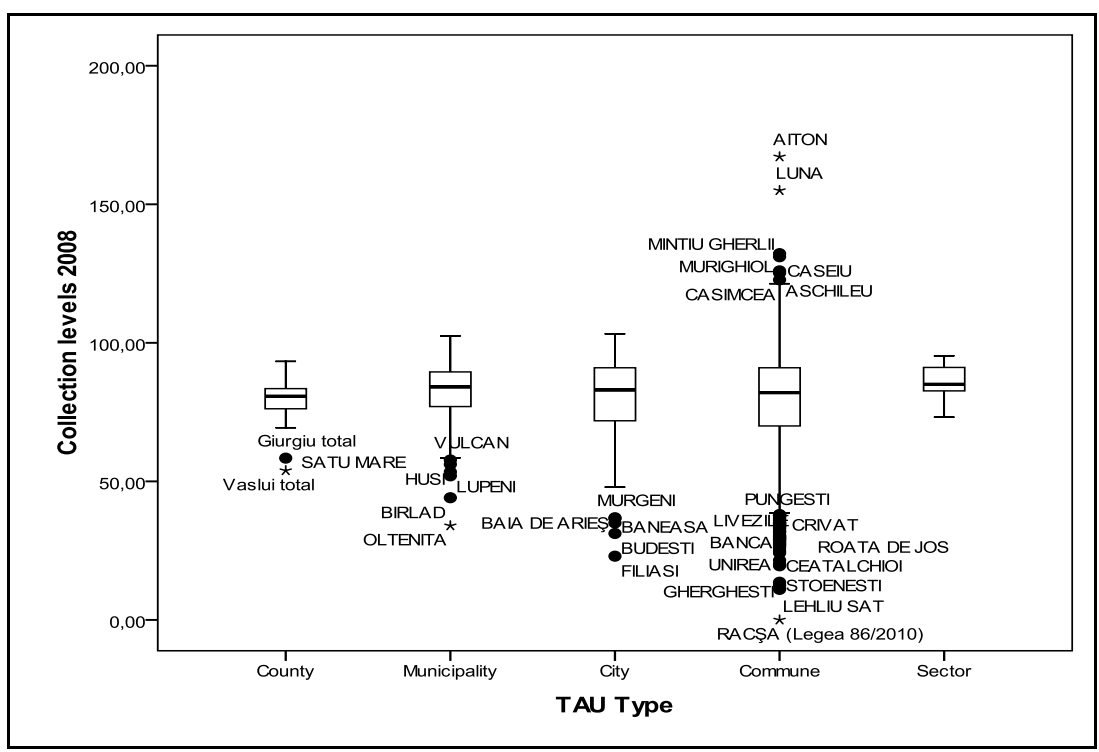

Source: authorial computation based on DFPLB (2013) data. 
Fig. 2: Collected/predicted re venues by t.a.u. type in 2009

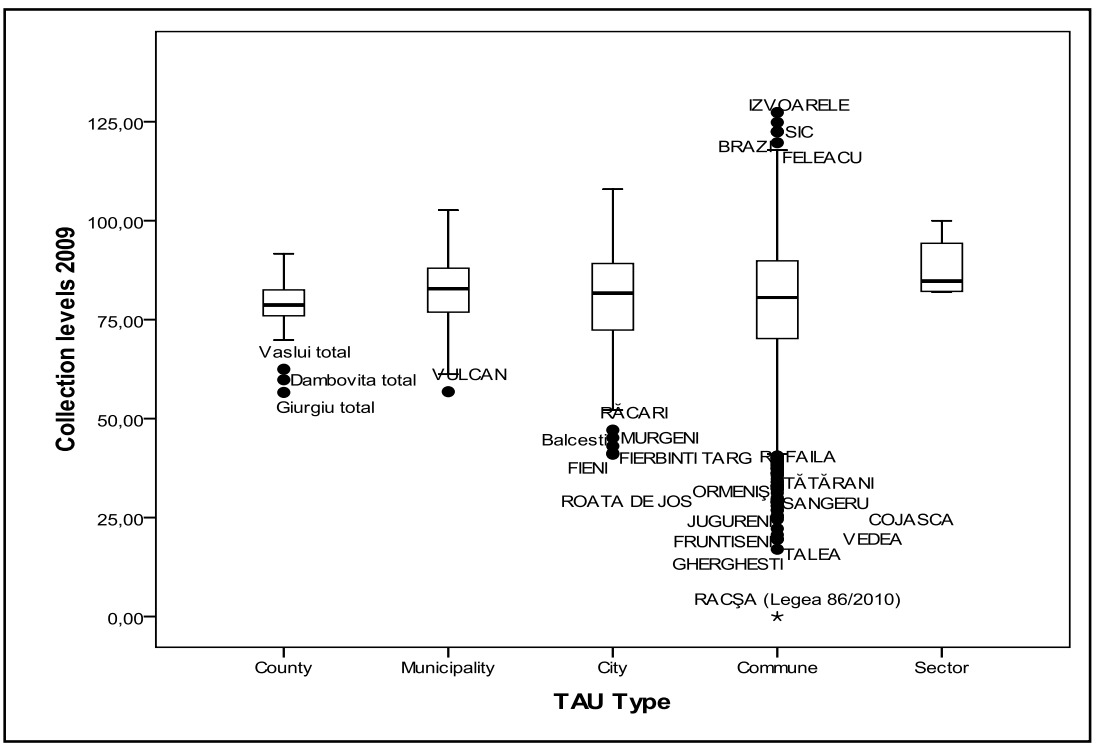

Source: authorial computation based on DFPLB (2013) data.

Fig. 3: Collected/predicted revenues by t.a.u. type in 2010

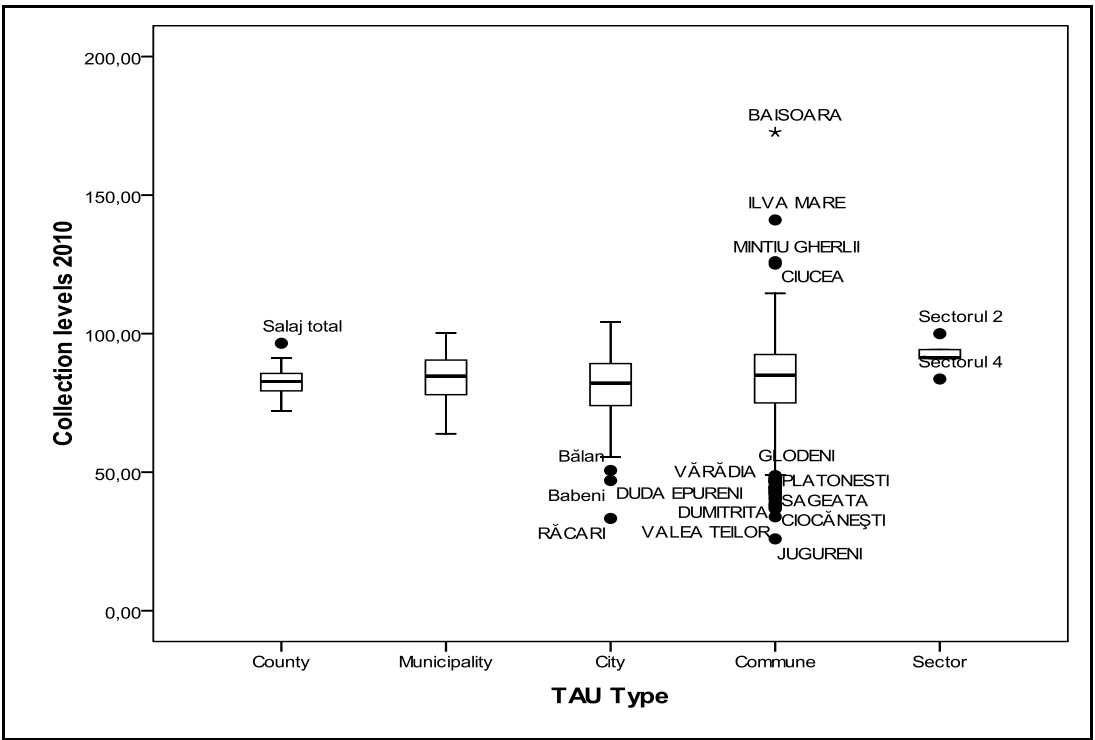

Source: authorial computation based on DFPLB (2013) data. 
Moldovan, O.: Local Revenue Mobilization in Romania.

Fig. 4: Collected/predicted revenues by t.a.u. type in 2011

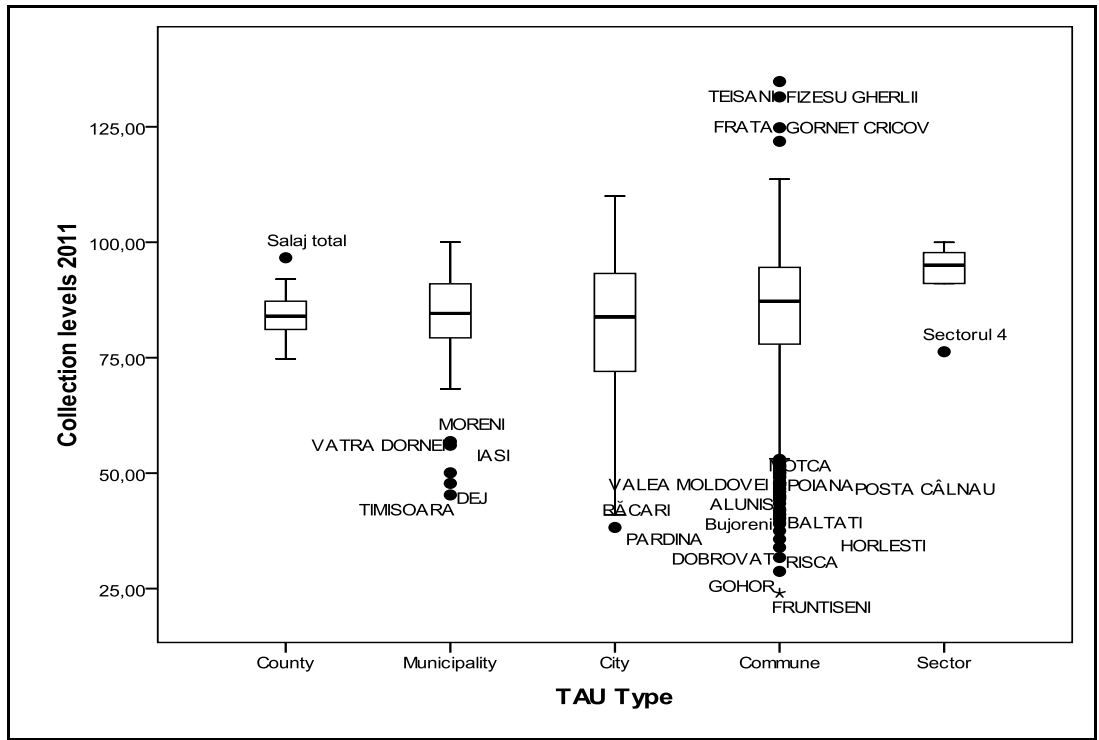

Source: authorial computation based on DFPLB (2013) data. 